\title{
Corporate Governance, Profitability, And Liquidity Against Tax Avoidance in Mining Companies Registered On The Indonesia Stock Exchange In 2012-2016
}

\begin{abstract}
Suri Mahrani
Faculty of Economics \& Business, Mercu Buana University Jakarta

Abstract

This research was motivated by the big news of tax evasion cases in the world including Indonesia, of course, namely Panama Papers and Paradise Papers. Many mining companies in Indonesia avoid taxes. Based on these tax avoidance issues, this study examines using mining companies listed on the Indonesia Stock Exchange (IDX) as a sample, because mining companies in Indonesia have a high enough potential to practice tax avoidance. Company data were sampled in this study from 2012-2016. This study seeks to find empirical evidence regarding the effect of corporate governance projected in the number of audit committees, the composition of independent commissioners and audit quality also by adding variable profitability and liquidity.
\end{abstract}

Keywords: corporate governance, profitability, liquidity, tax avoidance.

DOI: $10.7176 /$ RJFA/10-11-08

Publication date:June $30^{\text {th }} 2019$

\section{INTRODUCTION}

This research was motivated by the big news of tax avoidance cases in Indonesia including Indonesia, namely Panama Papers and Paradise Papers. Many mining companies in Indonesia avoid taxes. The issue of tax evasion is discussed in the international community, the leaked Panama Papers, and Paradise Papers. The scandal does not only remind us of the practice of concealment of wealth and the effort to avoid paying taxes outside the ordinary, which is commonly found in many cases illegal. But the leak of embarrassing data shows another thing: public trust is violated when companies, rich people and state officials can hide their money without breaking the law. This information leak also shows one other thing is public trust will be tarnished when large companies and rich and strong groups can hide their wealth without breaking the law.

Corporate governance is a system and structure that regulates the relationship between management and good owners who have a majority or minority shares in a company. Corporate governance is useful to protect investors from the difference in the interests of shareholders (principal) by the management (agent). In accordance with the 5 principles of corporate governance consisting of transparency, accountability, independence, responsibility, and fairness, companies should no longer practice tax avoidance. However, many companies that carry out tax avoidance prove that corporate governance has not been fully managed properly in accordance with these principles.

\section{Research Problem Formulation}

The problems to be examined in this study can be formulated as follows:

1. Does the number of audit committees affect the practice of tax avoidance?

2. Does the proportion of board of commissioners affect the practice of tax avoidance?

3. Does audit quality affect the practice of tax avoidance?

4. Does profitability affect the practice of tax avoidance?

5. Does liquidity affect the practice of tax avoidance?

\section{LITERATURE REVIEW}

Agency Theory (Agency Theory)

Jensen and Meckling (1976) describe the manager of a company as an agent and shareholder as principal. Shareholders who are principals delegate business decision making to managers who are representatives or agents of shareholders. The problem that arises as a result of the ownership system of companies such as this is that agents do not always make decisions that aim to fulfill the best interests of the principal.

\section{Tax evasion}

Corporate tax avoidance is one of the actions that are not socially responsible by the company, because companies that do tax avoidance are deemed not to contribute to the government in an effort to achieve public welfare, Landolf (2006) 


\section{Corporate Governance}

To solve agency problems and managerial opportunistic behavior, the application of corporate governance mechanisms can overcome these two problems, including regulating the high and low level of tax evasion carried out in accordance with the wishes of shareholders. There are various kinds of corporate governance definitions defined by various literature.

Corporate governance is a system, the company is directed and controlled. The board of directors is responsible for its corporate governance. The shareholders' role in governance is to appoint directors and auditors and to satisfy themselves that the structure of corporate governance is carried out as desired (Daves, 2006).

According to the Decree of the Minister of State-Owned Enterprises No. PER-01 / MBU / 2011, corporate governance is:

Good Corporate Governance hereinafter referred to as GCG, are the principles that underlie a process and mechanism for managing a company based on laws and business ethics.

In investigating the relationship between tax avoidance and corporate governance, this study focuses on the number of audit committees, the percentage of independent commissioners and audit quality.

Number of Audit Committees

To fulfill the requirements of good corporate governance principles, the company needs to have an audit committee to carry out the principles of responsibility and accountability as explained by KNKG. IDX requires all issuers to form and have an audit committee chaired by an independent commissioner, the audit committee functions as a supervisor in the process of making financial reports and internal supervision (Annisa, 2011).

The audit committee is measured by calculating the number of audit committees owned by the company, namely:

\section{$\operatorname{CoA}=\sum$ Audi committee $\mathbf{t}$}

Independent Board of Commissioners

The board of commissioners plays a central role in corporate governance because the law of the company focuses on legal responsibility for the company's affairs on the board of commissioners. Commissioners function is as a representative of shareholders for overseeing and advising the Board of Directors in order to carry out good corporate governance

The board of commissioners describes the culmination of a control system in large companies, which has a dual role, namely the role of monitoring and authentication (Antonia, 2008). Fama and Jensen (1983) stated that effective decision control is a positive function of the ratio of the external board of commissioners to the total membership of the board of commissioners.

The proportion of independent board of commissioners is measured using the percentage of independent commissioners on the total number of board of commissioners, which can be formulated, namely:

\section{Audit Quality}

The audit is a series of processes or procedures to reduce the inconsistency of information contained between managers and shareholders by using independent outside parties to provide endorsement of financial statements (Indah, 2010). The results of the financial statements audited by the auditor will be used by decisionmakers, therefore the quality of the audit must be maintained by the auditors so that decisions made by decision makers are right on target.

Audit quality is measured by the reputation of the KAP measured by the dummy variable, namely the value 1 for the Big 4 KAP and the value of 0 for the non-Big 4 KAP, formulated as follows:

$$
\operatorname{Aq}=1 ; A q=0
$$

Profitability

Profitability is a ratio used to measure a company's ability to generate profits from the normal activities of its business. The Company is an organization that operates with the goal of making a profit, by selling products (goods and /or services) to its customers. The operational goal of most companies is to maximize profits, short and long term. Management is required to improve yields (returns) to the owner of the company, as well as improve the welfare of employees. This can only happen if the company earns a profit in its business activities. This 
research is measured by Return on Assets (ROA).

Liquidity

Liquid assets are assets that are traded in active markets so that they can be converted into cash at prevailing market prices. While the liquidity position of a company is related to Is the company able to pay off its debt when the debt is due in the following year, Brigham \& Houston (2014). If the company has the ability to pay off its short-term obligations at maturity, the company is said to be a liquid company. To be able to fulfill its shortterm obligations that will soon be due, the company must have a level of availability of good cash or other current assets which can also be immediately converted or converted to cash. In this study using the Current Ratio (Current Ratio).

\section{LOGICAL FRAMEWORK}

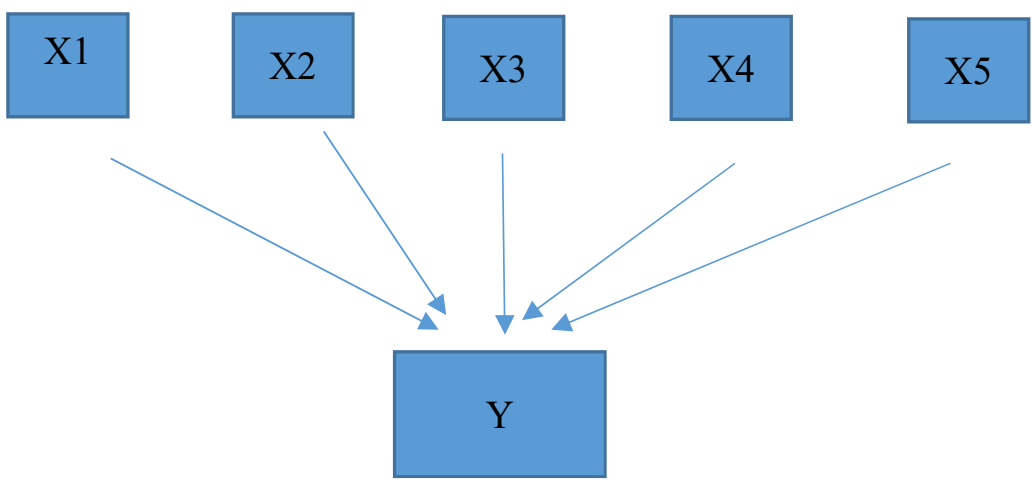

Figure 1. Framework for thinking

\section{HYPOTHESIS:}

1. Is the number of audit committees influencing the practice of tax avoidance?

2. The proportion of commissioners effect on the practice of tax evasion?

3. Quality of audits influence the practice of tax evasion?

4. Profitability effect on the practice of tax evasion?

5. Liquidity effect on the practice of tax evasion?

\section{RESEARCH METHODS}

The research used in this research is casual associative research. According to Sanusi (2011), associativecausal research is the search for the relationship between two or more variables. The purpose of associative research is to find a relationship between one variable and another variable.

\section{Research Population and Samples}

The population of this research is mining is which is listed on the Indonesia Stock Exchange 2012 2016 which is 42 companies.

Of the population is taken a number of specific samples using random sampling techniques Purposive. The sample used in this study was chosen based on the following criteria:

1. Registered as a mining sector company on the IDX.

2. Companies that continuously report their financial statements from 2012-2016.

3. Companies that have a net profit before tax are positive. 
According to the above criteria, the number of company samples used was 14 companies over 5 periods, namely $2012,2013,2014,2015,2016$. Then obtained the number of samples of 14 companies multiplied by 5 periods $=70$ data that will be used in this study.

\section{Data collection technique}

The data used in this study are time series data or time series data. According to Kuncoro (2009), sequential data of time is data arranged chronologically arranged according to time on a particular variable. This study uses sequential data on an annual basis from 2012 to 2016. The data collection methods used in this study are documentation methods. Method of documentation is done by collecting data from the literature that fit the theme of the study and the data from the financial statements contained in the Indonesia Stock Exchange (BEI) for the year $2012-2016$.

\section{Analysis}

\section{Statistical Analysis Description}

Descriptive statistics include minimum, maximum, mean and standard deviation. The data of the research variables include the dependent variable namely tax avoidance and the independent variables include the audit committee, the proportion of the board of commissioners, audit quality, profitability and liquidity. The results of the descriptive statistical analysis are shown in Table 5.1:

Table 5.1

\section{Results of descriptive statistics}

\begin{tabular}{|c|c|c|c|c|c|}
\hline & & & & Mean & Std. Dev \\
\hline ETR (Y) & 70 & .02 & 2.17 & .4322 & .39689 \\
\hline $\mathrm{CoA}(\mathrm{X} 1)$ & 70 & .0 & 5.0 & 3,086 & .8967 \\
\hline Propdk (X2) & 70 & .00 & .67 & .3685 & .14391 \\
\hline $\operatorname{Aq}(X 3)$ & 70 & .0 & 1.0 & .714 & .4550 \\
\hline ROA (X4) & 70 & .00 & .29 & .0674 & .05746 \\
\hline CR (X5) & 70 & .49 & 4.92 & 2.0561 & 1.06181 \\
\hline Valid N (listwise) & 70 & & & & \\
\hline
\end{tabular}

\subsection{Classical Assumption Test}

A model is stated to be good for predictors if it has the best liner unbiased estimator properties (Gujarati, 1997). Besides that a regression model is said to be quite good and can be used to predict if it passes a series of econometric assumptions that underlie it.

The classic assumption test is conducted to determine the condition of existing data in order to determine the most appropriate analysis model to use. The classic assumption test used in this study consisted of normality test, multicollinearity test, heteroscedasticity test, and autocorrelation test. Multicollinearity test using Variance Inflation Factors (VIF), heterosdasticity test using Glejser test. Autocorrelation test using DurbinWatson statistics.

\section{Normality Test}

The normality test aims to test whether in the regression model, the disturbing or residual variables have a normal distribution. As it is known that the $t$ test and $\mathrm{F}$ test assume that the residual value follows a normal distribution. If this assumption is violated, the statistical test becomes invalid for a small number of samples. A good regression model is to have normal data distribution. In principle, normality can be detected by looking at the spread of data (dots) on the diagonal axis of the graph or by looking at the residual histogram. Basic decision making as follows :

1. If the data spreads around the diagonal line and follows the direction of the diagonal line or the histogram graph shows a normal distribution pattern, the regression model meets the assumption of normality.

2. If the data spread far from the diagonal and / or do not follow the direction of the diagonal line or the histogram graph does not show a normal distribution pattern, then the regression model does not meet the assumption of normality.

3. 


\section{Normality Test Results}

Graph 5.2

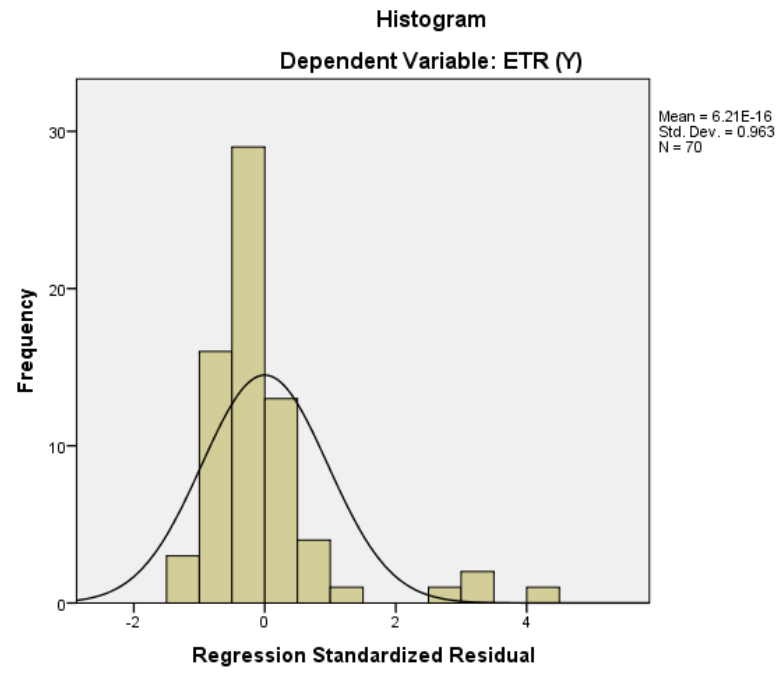

As per the graph the histogram above shows the data is not normally distributed. Judging from the histogram chart form is moderate positive skewness. So that data transformation is done. The form of data transformation that is done is SQRT (x) or square root. The following are the Kolmogorov-Smirnov test results after data transformation.

\begin{tabular}{|c|c|c|c|}
\hline & & & $\operatorname{ETR}(Y)$ \\
\hline $\mathrm{N}$ & & & 70 \\
\hline Normal Parameters $\mathrm{a}, \mathrm{b}$ & Mean & & .4322 \\
\hline & Std. Deviation & & .39689 \\
\hline Most Extreme Differences & Absolute & & .283 \\
\hline & Positive & & .283 \\
\hline & Negative & & -.195 \\
\hline Test Statistic & & & .283 \\
\hline Asymp. Sig. (2-tailed) & & & $.000^{\circ}$ \\
\hline Monte Carlo Sig. (2-tailed) & Sig. & & $.000^{\circ}$ \\
\hline & $99 \%$ Confidence Interval & Lower bound & .000 \\
\hline & & Upper Bound & .000 \\
\hline
\end{tabular}

\section{Multicolonity Test}

This test aims to test whether the regression model found a correlation between independent variables. A good regression model should not have a correlation between the independent variables. This test is done by using correlations between the independent variables used in the regression equation. If some or all of the independent variables are strongly correlated, it means that there is multicollinearity.

The method that can be used to test the presence of multicollinearity is to test the tolerance value or Variance Inflation Factor (VIF). The tolerance value limit is 0,10 and Variant Inflation Factor(VIF) is 10 (Hair et al ., 1998; 48). If the tolerance value is below 0, 10 or the Variance Inflation Factor (VIF) value is above 10 , multicollinearity occurs. 
Multicollinearity Test Result Table

Coefficients ${ }^{\text {a }}$

\begin{tabular}{|ll|r|r|}
\hline \multirow{2}{*}{ Model } & \multicolumn{2}{|c|}{ Collinearity Statistics } \\
\cline { 3 - 4 } & & Tolerance & \multicolumn{2}{|c|}{ VIF } \\
\hline 1 & (Constant) & & \\
& CoA (X1) & .683 & 1,464 \\
& Propdk (X2) & .880 & 1,136 \\
& Aq (X3) & .697 & 1,434 \\
& ROA (X4) & .890 & 1,123 \\
& CR (X5) & .846 & 1,183 \\
\hline
\end{tabular}

a. Dependent Variable: ETR (Y)

The results of the multicollinearity test show that there are no variables that have a tolerance value of less than 0.10 and there are no variables that have a VIF value of more than 10 . So it can be concluded that there is no multicollinearity in the regression model.

\section{Heteroscedasticity test}

Heteroscedasticity test aims to test whether in the regression model variance inequality occurs from one residual to another observation. If the variance from the residual one observation to another observation remains, then it is called homoskedasticity and if it is different it is called heteroscedasticity. A good regression model does not occur heteroscedasticity. Basic analysis as follows:

1. If there are certain patterns, such as the existing points form a certain pattern that is regular (wavy, widened and then narrowed), then it indicates that heteroscedasticity has occurred.

2. If there is no clear pattern, and the points spread above and below the number 0 on the $\mathrm{Y}$-axis, there is no heteroscedasticity.

Heteroskedasticity can be seen by looking at the scatterplot graph. Where the plot graph is the dependent variable namely SRESID with the residual ZPRED. The results of heteroscedasticity testing can be seen in the following graph:

\section{Graph 5 . 1 \\ Heteroscedasticity Test Results}

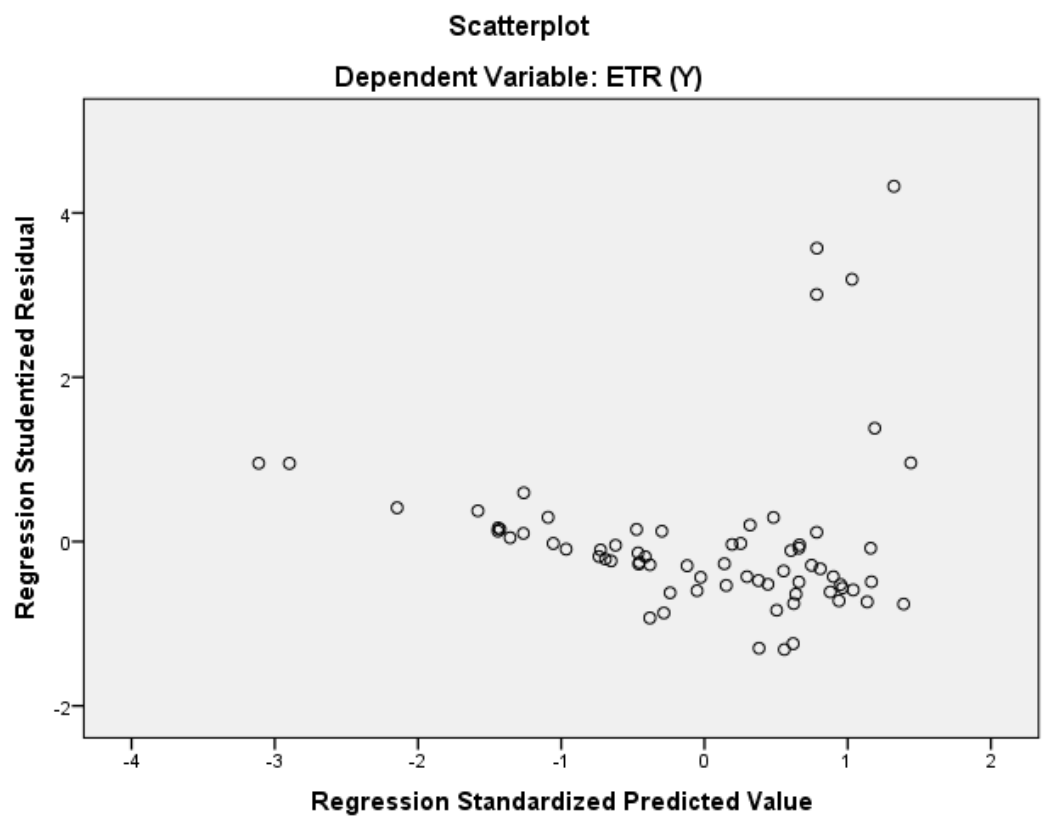




\section{Test Autocorrelation}

The autocorrelation test aims to test whether in the regression model there is a correlation between the confounding errors in period $\mathrm{t}$ and the interfering errors in the $\mathrm{t}-1$ period (before). The consequence of autocorrelation in a regression model is that the sample variant does not describe the population variant. Furthermore, the resulting regression model cannot be used to estimate the value of the dependent variable on the value of certain independent variables.

To diagnose the existence of autocorrelation in a regression model is done through the DurbinWatson test (DW- test) with the following conditions:
Less than 1,1
There is autocorrelation
1,1 to 1.54
Without conclusions
1,55 to 2.46
There is no autocorrelation
2, 46 to 2.9
Without conclusions
More than 2, 9
There is autocorrelation

Table 5.3

Autocorrelation Test

Model Summary ${ }^{b}$

\begin{tabular}{|l|r|r|r|r|r|}
\hline Model & \multicolumn{1}{|c|}{$\mathrm{R}$} & R Square & \multicolumn{1}{c|}{$\begin{array}{c}\text { Adjusted R } \\
\text { Square }\end{array}$} & $\begin{array}{l}\text { Std. Error of the } \\
\text { Estimate }\end{array}$ & Durbin-Watson \\
\hline 1 & $.399^{\mathrm{a}}$ & .159 & .093 & .37795 & 1,894 \\
\hline
\end{tabular}

a. Predictors: (Constant), CR (X5), ROA (X4), Propdk (X2), Aq (X3), CoA (X1)

b. Dependent Variable: ETR (Y)

From the table above, the value of Durbin-Watson is 1,894 , so it can be concluded that there is no autocorrelation in this regression model.

\subsection{Model Feasibility Test}

\subsubsection{Test The coefficient of determination $\left(R^{2)}\right.$}

This test shows the percentage of the ability of independent variables to explain the variation of dependent variable. The magnitude of the coefficient of determination from 0 to 1 . The closer to zero the magnitude of the coefficient of determination the smaller the influence of the independent variable, on the contrary, the closer to a magnitude of the coefficient of determination the greater the influence of independent variables. The test results are seen in the table.

Table 5.4

Results of the determination coefficient

Model Summary b

\begin{tabular}{|l|r|r|r|r|}
\hline Model & \multicolumn{1}{|c|}{$\mathrm{R}$} & R Square & \multicolumn{1}{c|}{$\begin{array}{c}\text { Adjusted R } \\
\text { Square }\end{array}$} & $\begin{array}{l}\text { Std. Error of the } \\
\text { Estimate }\end{array}$ \\
\hline 1 & $.399^{\mathrm{a}}$ & .159 & .10 & .37795 \\
\hline
\end{tabular}

a. Predictors: (Constant), CR (X5), ROA (X4), Propdk (X2), Aq (X3), CoA (X1)

b. Dependent Variable: ETR (Y) 
Based on table 5.4 can be seen that the coefficient number $(\mathrm{R})$ is 0,399 . The value of $\mathrm{R}$ ranges from 0 to 1 . If the value is close to 1 , then the relationship is getting tighter. Conversely, if it approaches 0 then the relationship gets weaker. $\mathrm{R}$ is obtained by 0,399 , which means that the correlation between the variables of profitability, ownership structure and size of the company to the capital structure is 0,529 . This means that there is a close relationship because the value is close to number 1 .

The Adjusted R Square number is 0.1 , this means that $10 \%$ of tax avoidance variables can be explained by proxy variables from corporate governance mechanisms, liquidity, and profitability. While the rest $(100 \%-10 \%$ $=90 \%)$ is explained by other reasons outside the model. The Adjusted R Square value can go up or down if one independent variable is added to the model.

\subsubsection{Test F Statistics}

Significance (F Test) is used to show whether all the independent variables included in the model have a joint effect on the dependent variable. (Ghozali, 2009). If the analysis using the F test shows that all independent variables simultaneously are explanations of the significance of the dependent variable.

Table 5.4

TEST F

ANOVA ${ }^{a}$

\begin{tabular}{|ll|r|r|r|r|r|}
\hline Model & & Sum of Squares & df & Mean Square & F & Sig. \\
\hline 1 & Regression & 1,727 & 5 & .345 & 2.418 & $.045^{\mathrm{b}}$ \\
& Residual & 9.142 & 64 & .143 & & \\
& Total & 10,869 & 69 & & & \\
\hline
\end{tabular}

a. Dependent Variable: ETR (Y)

b. Predictors: (Constant), CR (X5), ROA (X4), Propdk (X2), Aq (X3), CoA (X1)

Based on the table, it can be seen that $\mathrm{F}$ count is 2.418 with a probability of 0,045 . This shows that $\mathrm{p}$ value (0.045) <significance level (0.05), means that the regression model can be used to predict tax avoidance, or all dependent variables, namely the audit committee, the proportion of independent commissioners, audit quality, profitability and liquidity together significant effect on tax avoidance.

\subsection{3 . Test Statistics $t$}

A statistical test $t$ is carried out to explain the independent variable coefficients can use unstandardized coefficients or standardized coefficients. 


IIS

\begin{tabular}{|c|c|c|c|c|c|c|}
\hline & & \multicolumn{5}{|c|}{ Coefficients ${ }^{\text {a }}$} \\
\hline \multirow{2}{*}{\multicolumn{2}{|c|}{ Model }} & \multicolumn{2}{|c|}{$\begin{array}{c}\text { Unstandardized } \\
\text { Coefficients }\end{array}$} & \multirow{2}{*}{$\begin{array}{c}\begin{array}{c}\text { Standardized } \\
\text { Coefficients }\end{array} \\
\text { Beta }\end{array}$} & \multirow[b]{2}{*}{$\mathrm{t}$} & \multirow[b]{2}{*}{ Sig. } \\
\hline & & B & Std. Error & & & \\
\hline \multirow[t]{6}{*}{1} & (Constant) & .665 & .277 & & 2,399 & .19 \\
\hline & CoA (X1) & .26 & .061 & .058 & .421 & .675 \\
\hline & Propdk (X2) & -.357 & .337 & -129 & -1.059 & .293 \\
\hline & $\mathrm{Aq}(\mathrm{X} 3)$ & .006 & .2020 & .007 & .052 & .959 \\
\hline & ROA (X4) & $-2,768$ & .839 & -.401 & $-3,298$ & .002 \\
\hline & CR (X5) & .000 & .47 & .001 & .009 & .993 \\
\hline
\end{tabular}

a. Dependent Variable: ETR (Y)

\section{4 . Multiple Linear Regression}

In accordance with the results of the research hypothesis which states that the audit committee variable (CoA) and the proportion of independent commissioners (Propdk), audit quality (Aq), probability (ROA), and liquidity (CR) have an influence on tax avoidance (ETR) for that multiple linear regression to make an analysis model. The multiple linear regression equation models are as follows:

$$
\mathrm{Y}=\mathbf{0}, 665+0.026 \mathrm{CoA}-0,357 \text { Propdk + 0,006Aq - 2,768 ROA + 0, } 0 \text { CR + e }
$$

From the regression equation above can be concluded as follows:

1. The constant of 0.665 states that if CoA, Propdk, Aq, ROA, and CR have constant values, then ETR up by $66.5 \%$.

2. The Audit Committee (CoA) regression coefficient of 0.026 states that each increase in the number of audit committees will be followed by an increase in tax avoidance of $2,6 \%$.

3. The regression coefficient Proportion of Independent Commissioner Board (Propdk) amounted to - 0.357 declare an increase in the number of the independent board will be followed by a decline in tax evasion by $35,7 \%$.

4. The Audit Quality regression coefficient of 0.006 states that any increase in audit quality will be followed by an increase in tax avoidance practices of $0,6 \%$.

5. Probability regression coefficient (ROA) of $-2,768$ states that every increase in probability value then the practice of corporate tax avoidance will decrease by $276,8 \%$.

6. The regression coefficient of Liquidity (CR) of 0,000 means that every increase in company liquidity will increase the practice of tax avoidance by $0.00 \%$

\section{DISCUSSION}

1. Effect of the Number of Audit Committees on Tax Avoidance 
The results of the study that the Number of Audit Committees had no effect on Tax Avoidance, meant that hypothesis 1 was rejected. Based on the research, the number of audit committees was a lot or little did not affect the practice of tax avoidance.

2. Effects of the Independent Board of Commissioners' Proportion on Tax Avoidance.

The results of the study that the proportion of the Independent Board of Commissioners does not affect Tax Avoidance means that hypothesis 2 is rejected. An independent board of commissioners is a commissioner who does not originate from an affiliated party or a party that has a business relationship and kinship with the controlling shareholder, members of the board of directors and other board of commissioners, and the company itself, KNKG (2006). The board of commissioners has a function and responsibility as a supervisor of company management policies so that it is not directly related to the company's taxation activities.

3. Effects of Audit Quality on Tax Avoidance

The results of the study that Audit Quality does not affect the practice of Tax Avoidance. In other words, good audit quality from the best reputation KAP (big 4) does not guarantee that audited financial statements are of good quality, for example, many cases of financial report manipulation carried out by the reputable KAP

\section{Effect of Profitability on Tax Avoidance}

The results of the study that Profitability affects the practice of Tax Avoidance, means that hypothesis 4 is accepted. The high and low value of profitability affects tax avoidance. In other words the higher the profit of a company, the higher the tax that must be paid by the company, the lower the practice of tax avoidance. Whereas if company profits decrease or profitability is low then the practice of tax avoidance is higher, because the results of the study show a negative influence

\section{Effect of Liquidity on Tax Avoidance}

The results showed that liquidity did not affect the practice of tax avoidance, meaning hypothesis 5 was rejected. The level of liquidity is the company's ability to pay its current liabilities, current liabilities, one of which is the tax burden. In other words liquid or not the company does not affect the practice of tax avoidance.

\section{CONCLUSION}

Based on the results of the research partially and the discussions that have been conducted, conclusions can be given as follows:

1. The Audit Committee has no effect on tax avoidance.

2. The number of Independent Commissioners does not affect tax avoidance

3. Audit quality does not affect tax avoidance

4. The probability of having an effect on tax avoidance

5. Liquidity does not affect tax avoidance.

\section{SUGGESTION}

This study has limitations. But the results of this study are expected to motivate the conduct of subsequent research. Taking into account the limitations that exist, it is hoped that future research will improve the following factors: 
1. This research is only limited to empirical studies of the factors that influence tax avoidance on existing mining companies go public on the IDX but not to solve the problem of how the impact of tax evasion itself. Therefore, other researchers who are interested in the problem of corporate tax avoidance can develop this research in order to find out the impact of tax avoidance that companies use on government revenues, regional development and the advancement of education in Indonesia.

2. This research was conducted using data from $2012-2016$, so that for other years or years to come, the results of this study still need to be tested again.

3. In further research it is expected to provide a broader picture to take other types of industries that have adequate samples.

\section{BIBLIOGRAPHY}

Adiyani, Novita. (2017). Effect of Liquidity and Profitability on Tax Aggressiveness with CSR as an Intervening Variable. Accounting journal.

Annisa and Kurniasih. (2012). Influence of Corporate Governance Against Tax Avoidance. Accounting journal. Sebelas Maret University.

Brigham and Houston (2014), Essentials of Financial Management, Cengage Learning

Cahyono, et al. (2016). Effects of the Audit Committee, Institutional Ownership, Board of Commissioners, Company Units (SIZE), Leverage (DER) and Profitability (ROA) Against Tax Avoidance. Journal of Accounting. FEB Unpad.

Damayanti and Susanto. (2015). Effects of the Audit Committee, Audit Quality, Institutional Ownership, Corporate Risk and Return of Assets on Tax Avoidance. Essence of the Business and Management Journal.

Danced and Ulupui. (2016). Effects of the Audit Committee, Proportion of Independent Board of Commissioners, and Proportion of Institutional Ownership of Tax Avoidance. E-Journal of Accounting.Udayana University.

Davis, Keith. (2007). Behavior in Organizations. Erlangga Publisher. Jakarta.

Damodar, Gujarati (2008), Basic Econometrics, Fifth Edition, McGraw Hill Education

Efendy, Arief. (2009). The Power of Corporate Governance: Theory and Implementation. Salemba Empat. Jakarta

Fadhilah, Rahmi. (2014). Influence of Corporate Governance Against Tax Avoidance. Accounting journal. Padang State University.

Friese, Arne. (2006). Taxation and Corporate Governance. www.ssrn.com.

Ghozali, I. (2016). Application of Multivariate Analysis with IBM SPSS 23 Program Update on PLS Regression, Edition 7. Diponegoro University Publishing Agency. Semarang.

Jensen, MC, and Meckling, WH (1976). Theory of the firm: managerial behavior, agency costs, and ownership structure. Journal of Financial Economics.

Khoirunnisa. (2015). Influence of Corporate Governance Against Tax Avoidance. Accounts Journal.

National Governance Policy Committee. (2016). General Guidelines for Good Corporate Governance in Indonesia. Jakarta.

Kountur, Ronny. (2007). Research Methods for Thesis Writing and Thesis Revised Edition. PPM Publisher. Jakarta

Landolf, Urs. (2006). Tax and Corporate Responsibility. International Tax Review.

Lukviarman, Niki (2016), Corporate Governance, PT. Era Adicitra Intermedia, Solo

Lumbantoruan, Sophar. (2006). Tax Accounting Revised Edition. PT Gramedia Widiasarana Indonesia. Jakarta.

Maharani and Suardana. (2014). Effect of Corporate Governance, Profitability,

and Characteristics of Executives on Tax Avoidance. E-journal of Accounting. Udayana University.

Nazaruddin and Basuki. (2016). Statistical Analysis with SPSS. Danis Media. Sleman.

Pradipta and Supriyadi. (2015). Effect of Corporate Social Responsibility (CSR), Profitability, Leverage, and Independent Commissioners on Tax Avoidance Practices. Accounting journal. Gajah Mada University.

Purwanto, Agus. (2016). Effect of Liquidity, Leverage, Profit Management and Fiscal Loss Compensation Against Tax Aggressiveness. JOM Fekon.

Puspita and Harto. (2014). Effect of Corporate Governance on Tax Avoidance. Diponegoro Journal of Accounting. Diponegoro University. 